\title{
The Effects of 10-hr Construction Outreach Training: Knowledge Retention and Practical Application
}

\author{
Koshy Koshy (Corresponding author) \\ Rutgers School of Public Health \\ 683 Hoes Lane West, Suite 110, Piscataway, New Jersey, 08854, United State of America
}

Tel: 732-235-9459 Fax: 732-235-9460

E-mail: koshyko@rutgers.edu

Mitchel A. Rosen

Rutgers School of Public Health

683 Hoes Lane West, Suite 110, Piscataway, New Jersey, 08854, United States of America

Tel: 732-235-9452 Fax: 732-235-9460

E-mail: mrosen@rutgers.edu

Michael Presutti

Rutgers School of Public Health

683 Hoes Lane West, Suite 110, Piscataway, New Jersey, 08854, United States of America E-mail: presutmj@sph.rutgers.edu

Mehul A. Patel

Rutgers School of Public Health

683 Hoes Lane West, Suite 110, Piscataway, New Jersey, 08854, United States of America E-mail: patelme@rutgers.edu

Received: May 7, 2015 Accepted: May 27, 2015 Published: June 30, 2015

doi:10.5296/jss.v1i1.7560ＵRL: http://dx.doi.org/10.5296/jss.v1i1.7560 


\begin{abstract}
Many states and municipalities today require the completion of 10-hr Construction Outreach Training as a prerequisite for entrance into jobsites. Over 500,000 workers received the OSHA Construction Outreach Training in FY 2013. Rutgers OSHA Training Institute Education Center (OTIEC) recruited a cohort of Construction Outreach Trainers to administer a survey to their students to identify their motivations for attending the trainings, the knowledge gained in certain subject areas and how the students expected to practically apply the knowledge gained in the training to actual worksites. A majority of the over 600 students participating in the study demonstrated a significant depth in subject matter knowledge and practical ability to connect hazard controls to effectively mitigate risks. Students were able to identify deficiencies at their workplaces regarding the lack of hazard-specific training and various administrative controls. This study also identified several issues concerning the length of time trainers currently allocate for the safety and health topics and some strategies to realign these durations to maximize the effectiveness and efficiency of various trainings.
\end{abstract}

Keywords: Construction Outreach Training, Evaluation, OSHA Training Institute

\title{
1. Introduction
}

Due to high and disproportionate number of injuries and fatalities in the construction industry, safety is a major concern in the United States affecting many stakeholders. In 2011, the construction industry accounted for $16 \%$ of fatal occupational injuries while employing only $4 \%$ of the workforce (BLS, 2013). Improving workers' ability to more readily recognize, assess and control workplace hazards through training is a long-standing and proven means of reducing the number of injuries and fatalities on construction worksites (Albert, Hallowell, Kleiner, Chen \& Golpavar-Fard, 2014).

The OSHA Outreach Training Program, initiated in the Occupational Safety Act of 1970 and developed by the OSHA Training Institute (OTI) is an awareness training that enhances workers ability to recognize, avoid, abate, and prevent safety and health hazards at the worksite (OSHA, 2014). Approximately 2.3 million workers received the 10-hr Construction Outreach Training between 2004 and 2008 (Fechhelm, 2010).

A 10-hr Construction Outreach Training is required to include (1) Introduction to OSHA (2-hours) (2) Construction Focus Four Hazards (4-hours) (3) Personal Protective Equipment (0.5 hours) and (4) Health Hazards in Construction (0.5 hours). OSHA authorized trainers can use the remaining elective hours to dedicated topics included in 29CFR1926 (OSHA, 2014).

Several states require completion of the 10-hr Construction Outreach Training for employment (Connecticut, Massachusetts, Missouri, Nevada, New Hampshire, New York, and Rhode Island) on construction sites. Additionally, the City of New York requires construction workers to complete a 10-hour construction course every five years (Fechhelm, 2010; NYC, 2014).

Rutgers School of Public Health is one of 27 training organizations within the OSHA Training Institute Education Center (OTIEC) consortium that administers the OSHA 
Outreach Trainer Program. Outreach authorized training credentials are granted to trainers who successfully complete a series of courses offered at the OTIEC (OSHA, 2014).

This study examines various motivations of those workers who attended the sample group of OSHA 10-hr Construction Outreach Trainings, the transfer of knowledge respective to safety and health in the workplace, selected strategies identified for the implementation of such knowledge at worksites and perceived limitations in the program.

\section{Background}

Every year approximately 4,500 workers die on the job and more than 3 million are injured (BLS, 2014). Training is an important and widely proven tool for improving work practices and enhancing hazard identification skills leading to workers suffering fewer accidents and exposures (Ruttenberg, 2013). Employer initiated training that provides employees with the skills to recognize, understand, avoid and work with the actual hazards they face provides a great opportunity to improve workplace safety and health.

A key to effective safety management is the worker's ability to sense, analyze, and extract physical stimuli that indicate the presence of hazardous conditions. This skill is classified as hazard recognition. Recent studies have shown that newer employees failed to detect $57 \%$ of hazards in their work environments (Bahn, 2013). Carter \& Smith (2006) concluded that 10 to $33.5 \%$ of the hazards at the worksite remain undetected. The inability to conduct an effective hazard assessment may be the cause for these disproportionate injury rates. Researchers have documented the reduction in injury and lost workdays associated with comprehensive tool box training and through safety orientation in the construction industry. Occupational safety and health training has also been linked to significant improvements in site housekeeping, leading to better working conditions (Dong, Entzel, Men, Chowdhury \& Schneider, 2004).

This study identifies the effectiveness of the 10-hr Construction Outreach Training by assessing the knowledge gained in the individual subject areas and strategies the students identified for implementing controls at the worksite, based upon knowledge gained from respective training.

\section{Methods}

Construction Outreach Trainers who completed their OSHA 500 Trainer for Construction course at Rutgers and met the following inclusion criteria were selected to participate in the study:

1. Minimum five years of Construction Outreach Training Experience

2. Conducted three or more 10-hr Construction trainings every year since October 1, 2008

3. Compliant with the 2014 OSHA Outreach Monitoring and Records Audit Guidelines

From a group of 471 Rutgers Outreach trainers who provided construction training in FY 2013 (October 1, 2012 to September 30, 2013), 23 trainers met the criteria and were invited to participate in the study. Thirteen of them agreed to participate. The study was conducted between April 1, 2014 and September 30, 2014. 


\section{Macrothink

At the end of each training students completed the survey presented in Appendix 1. The survey was approved by the Rutgers Institutional Review Board (IRB) and included nine demographic questions, eight discrete questions, which required a "yes" or "no" answer, followed by seven open-ended questions where students could elaborate more freely. The open-ended questions were designed to evaluate student overall satisfaction with the training, the current safety culture at their worksite, and provide additional comments related to the discrete questions so as to assess how the information they gained in the training sessions would apply to their worksites.

\section{Results}

Ten of the thirteen trainers who volunteered to participate in the study participated. Over a six-month period of time, the study was administered in 40 training sessions with a total of 642 students participating. Student demographics are summarized in Table 1. Eighty-eight (88\%) of the participants reported that they were taking the class as a requirement of their employment. This was expected since 36 of the sessions were conducted in New York City, where workers are required to complete an OSHA10-hr Construction course within five previous calendar years for entrance onto major-building construction worksites required under New York City's 2008 Building Code. Five percent of these students possess industry specific certifications, including the Certified Industrial Hygienist (CIH), Construction Health and Safety Technician (CHST), Occupational Health and Safety Technician (OHST), and Professional Engineer (PE).

Student satisfaction with different aspects of the training are reported in Table 2. Participants reported 100\% satisfaction with the elements of instructor encouraging their participation and answering their safety and health questions. While $89 \%$ of the respondents were able to identify changes at their worksite and $97 \%$ were comfortable bringing suggestions for safety and health changes to their employer. The remaining four questions identified their overall satisfaction with the knowledge gained in the required subject areas. 
Table 1. 10-hr Construction Training Participant Demographic from this Study

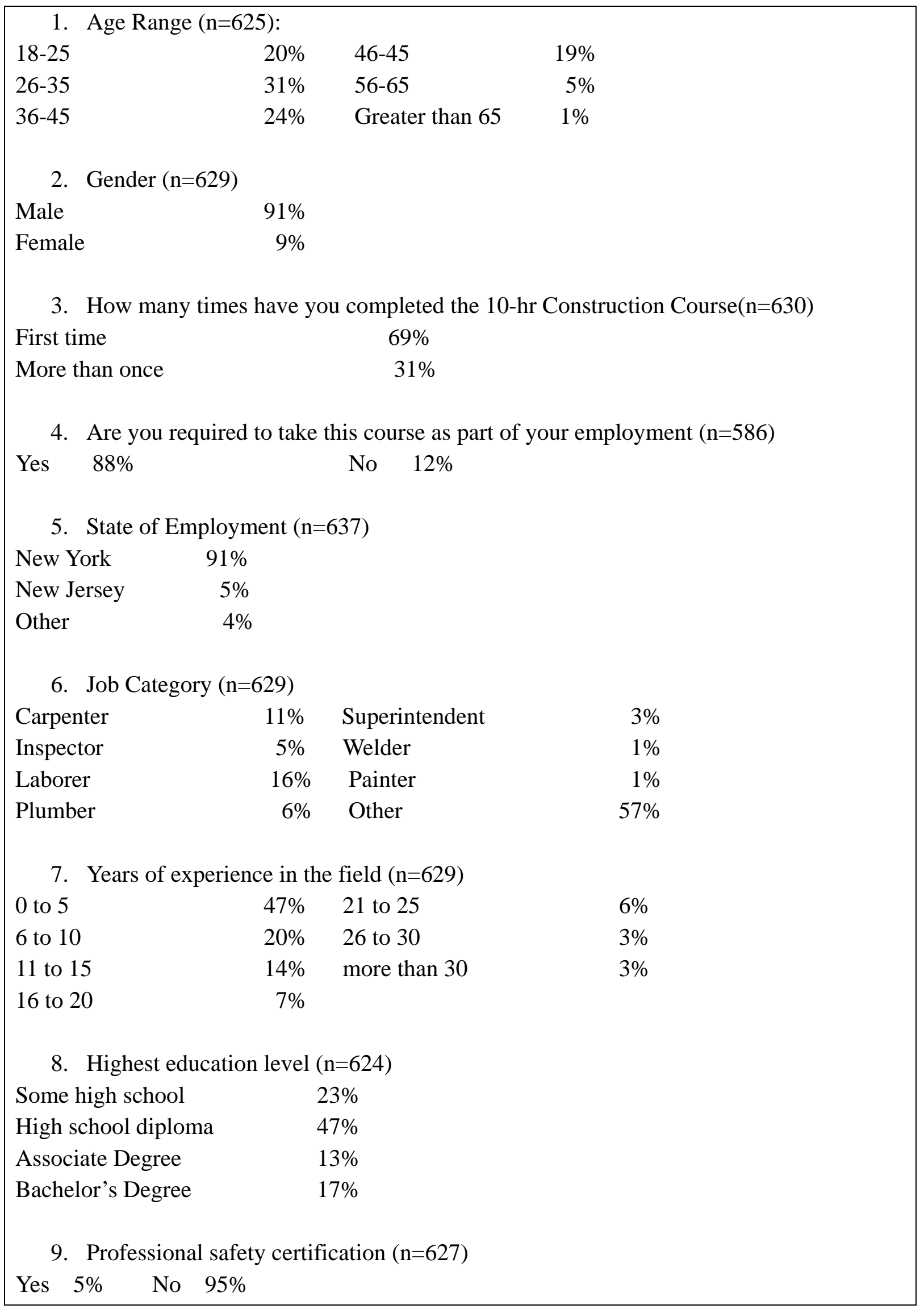


Table 2. Students Perception of the Training

\begin{tabular}{|l|l|l|}
\hline Question & Yes & No \\
\hline Did the instructor encourage student participation? (n=640) & $100 \%$ & $0 \%$ \\
\hline $\begin{array}{l}\text { Were your safety and health questions answered in the class? } \\
\text { (n=635) }\end{array}$ & $100 \%$ & $0 \%$ \\
\hline $\begin{array}{l}\text { Were you able to identify changes to work practices at your site, } \\
\text { based on the information you learned in this training? (n=638) }\end{array}$ & $89 \%$ & $11 \%$ \\
\hline $\begin{array}{l}\text { Do you feel comfortable bringing suggestions for safety and } \\
\text { health changes to your supervisor and management? (n=631) }\end{array}$ & $97 \%$ & $3 \%$ \\
\hline $\begin{array}{l}\text { Intro to OSHA: Did you learn something new about worker } \\
\text { protection? (n=628) }\end{array}$ & $96 \%$ & $4 \%$ \\
\hline PPE: Did you learn something new about PPE? (n=633) & $90 \%$ & $10 \%$ \\
\hline $\begin{array}{l}\text { Health Hazards in Construction: Did you learn something new? } \\
\text { (n=624) }\end{array}$ & $87 \%$ & $13 \%$ \\
\hline Focus-4: Did you learning something new? (n=630) & $91 \%$ & $9 \%$ \\
\hline
\end{tabular}

Responding students provided a total of 165 comments when asked "if they identified changes in work practices as a result of attending this training" and are summarized in Table 3. The majority of comments (60.6\%) related to changes they expect to make in administrative controls they identified as a result of attending this training. They included more diligence in selecting and using of ladders, installing warning signs, utilizing other resources available to them at their site including safety data sheets (SDS) and identifying those in authority, including the competent person. Several students asserted that the OSHA 10-hr Construction training program was not enough to meet their task specific training needs, including hazards associated with crane, scaffolding, and trenching. These students also reported 54 changes expected to be made related to Personal Protective Equipment (PPE) including wearing them more diligently, understanding the role that American National Standards Institute (ANSI) and the National Institute for Occupational Safety and Health (NIOSH) play in the testing process and checking for their approval stickers and labels in their equipment, and paying closer attention to applicable expirations. 


\section{Macrothink}

Table 3. Changes identified to work practices as a result of attending training $(n=165)$

\begin{tabular}{|c|c|c|c|}
\hline $\begin{array}{c}\text { Number } \\
\text { of } \\
\text { Responses }\end{array}$ & $\begin{array}{l}\% \text { of valid } \\
\text { responses }\end{array}$ & $\begin{array}{l}\text { Control } \\
\text { Measure }\end{array}$ & Summary of Comments \\
\hline 54 & $34.8 \%$ & PPE & $\begin{array}{l}\text { - Wear hearing protection and safety goggles } \\
\text { - Inspect PPE to make sure they meet ANSI or } \\
\text { NIOSH Approval, } \\
\text { - More care in storage and maintenance and } \\
\text { - } \text { making sure they haven’t expired. } \\
\text { - Use PPE more diligently }\end{array}$ \\
\hline 7 & $4.5 \%$ & Engineering & $\begin{array}{l}\text { - Use water to suppress dust } \\
\text { - Use precautions while working in a trench } \\
\text { - Cap rebar } \\
\text { - Ventilate work area while using gasoline }\end{array}$ \\
\hline 94 & $60.6 \%$ & Administrative & $\begin{array}{l}\text { - Identify the competent person on the jobsite } \\
\text { - Exercise more diligence in selecting, using, } \\
\text { and storing portable ladders } \\
\text { - } \quad \text { Secure holes in the floor } \\
\text { - } \quad \text { Review Safety Data Sheets (SDS) } \\
\text { - Complete task specific training beyond 10-hr } \\
\text { - Construction (Cranes, Scaffolds, Trenching) } \\
\text { - } \text { Perform worksite hazard analysis and inspect } \\
\text { - Install more warning signs }\end{array}$ \\
\hline 10 & & & Comments not directed to the question \\
\hline
\end{tabular}

A total of 182 comments were provided by these students when asked if they were able to bring safety and health concerns to their management (Table 4). More than half of them (53.3\%) were testimonials to their relationship with management and effective policy in regard to their safety. Several students mentioned that they needed to request more time from their employers to inspect their equipment and that employers were obligated to provide personal protection equipment. Thirty-five students also noted that they would file complaint with OSHA if their employer didn’t take the necessary steps to improve their workplace safety. 


\section{Macrothink}

Table 4. Bringing safety and health concerns to management $(n=182)$

\begin{tabular}{|l|l|l|l|}
\hline $\begin{array}{c}\text { Number } \\
\text { of } \\
\text { Responses }\end{array}$ & $\begin{array}{l}\text { \% of Valid } \\
\text { Responses }\end{array}$ & $\begin{array}{c}\text { Actions } \\
\text { Identified from } \\
\text { Attending } \\
\text { Training }\end{array}$ & \multicolumn{1}{c|}{ Summary of Comments } \\
\hline 44 & $26.0 \%$ & $\begin{array}{l}\text { Action based on } \\
\text { knowledge } \\
\text { gained }\end{array}$ & $\begin{array}{l}\text { - } \\
\text { Request more time to inspect equipment } \\
\text { Management must provide PPE }\end{array}$ \\
\hline 35 & $20.7 \%$ & $\begin{array}{l}\text { Additional } \\
\text { resources }\end{array}$ & $\begin{array}{l}\text { File a complaint if management doesn't } \\
\text { take action }\end{array}$ \\
\hline 90 & $53.3 \%$ & $\begin{array}{l}\text { Current Safety } \\
\text { Climate }\end{array}$ & $\begin{array}{l}\text { Comfortable bringing questions and } \\
\text { suggestions to management. } \\
\text { Employer values workers as a valuable } \\
\text { resource }\end{array}$ \\
\hline 13 & & & \begin{tabular}{l} 
Comments not directed to the question \\
\hline
\end{tabular} \\
\hline
\end{tabular}

Student feedback related to new information they learned from the Introduction to OSHA section are summarized based on who they felt should execute it - employee, employer, or both. Nearly two thirds (63.9\%) of the valid responses were directed to actions that workers needed to take including filing a complaint with OSHA, remaining vigilant to worksite safety issues, and refusing to work under unsafe conditions. Almost one third (31.9\%) of the comments were responsibilities the employer needed to take including providing workers a worksite free of recognized hazards, conducting hazard analysis, and providing their workers PPE. Three students answered that safety should be a shared responsibility between the employers and employees. These data are summarized in Table 5. 
Table 5. Knowledge Gained from the Introduction to OSHA Section of the training $(n=238)$

\begin{tabular}{|c|c|c|c|}
\hline $\begin{array}{l}\text { Number } \\
\text { of } \\
\text { Responses }\end{array}$ & $\begin{array}{l}\% \text { of Valid } \\
\text { Responses }\end{array}$ & $\begin{array}{l}\text { Role or } \\
\text { Responsible } \\
\text { Party }\end{array}$ & Summary of Comments \\
\hline 23 & $31.9 \%$ & Employer & $\begin{array}{l}\text { - Employer is responsible for providing workers a } \\
\text { - Unorksite free of recognized hazards } \\
\text { responsibility to provide workers healthy and } \\
\text { safe work environment } \\
\text { - Worksites are expected to have a competent } \\
\text { person } \\
\text { - Employers are responsible for conducting hazard } \\
\text { - } \text { analysis } \\
\text { - EsHA can fine the employer } \\
\text { - Eliminating the hazard is the best control } \\
\text { - Employers must provide PPE }\end{array}$ \\
\hline 46 & $63.9 \%$ & Employee & $\begin{array}{l}\text { - OSHA protects workers } \\
\text { - Workers have the right to understand the hazard } \\
\text { at their worksite } \\
\text { - Workers should remain alert to hazards } \\
\text { - Workers can report hazardous conditions to } \\
\text { OSHA } \\
\text { - OSHA rights extend to undocumented workers } \\
\text { - Workers can file an } 11(\mathrm{C}) \text { complaint } \\
\text { - Workers can refuse to work under unsafe } \\
\text { conditions }\end{array}$ \\
\hline 3 & $4.2 \%$ & $\begin{array}{l}\text { Employee } \\
\text { and } \\
\text { Employer }\end{array}$ & $\begin{array}{l}\text { - Safety is a shared responsibility between } \\
\text { employers and employees }\end{array}$ \\
\hline 166 & & & Comments not directed to the question \\
\hline
\end{tabular}

From a regulatory perspective, students identified that employers were required to assess their PPE needs, provide it to them at no charge, and train them how to use it properly. From a usage perspective, they understood that PPE should be selected based on the nature of the hazard and most importantly, PPE had limitations including expiration and potential for failure. Student feedback on the knowledge they gained regarding PPE is summarized in Table 6. 
Table 6. Knowledge gained related to Personal Protective Equipment (PPE) (n=192)

\begin{tabular}{|c|c|c|c|}
\hline $\begin{array}{c}\text { Number } \\
\text { of } \\
\text { Responses }\end{array}$ & $\begin{array}{l}\% \text { of Valid } \\
\text { Responses }\end{array}$ & $\begin{array}{l}\text { Areas of } \\
\text { Concern }\end{array}$ & Summary of Comments \\
\hline 83 & $45.9 \%$ & Regulation & $\begin{array}{l}\text { - } \\
\text { - Smployers must provide PPE } \\
\text { PPE } \\
\text { - Workers must be trained to use all } \\
\text { PPE }\end{array}$ \\
\hline 75 & $41.4 \%$ & Using PPE & $\begin{array}{l}\text { - Inspect equipment before use and } \\
\text { check for worn parts (PFAS } \\
\text { mentioned) } \\
\text { - PPE should be selected based on work } \\
\text { conditions. Safety glasses, gloves, and } \\
\text { hardhats must be selected based on job } \\
\text { situation. }\end{array}$ \\
\hline 23 & $12.7 \%$ & Limitation & $\begin{array}{l}\text { - All PPE expires } \\
\text { - PPE is the last line of defense. } \\
\text { Workers wearing PPE may still be } \\
\text { injured }\end{array}$ \\
\hline 11 & & & Comments not directed to the question \\
\hline
\end{tabular}

The majority of information these students reported gaining in health hazards was related to hazardous materials (98.5\%). Many of the comments were related to learning about the Global Harmonization System (GHS) and understanding the importance of consulting the Safety Data Sheets (SDS) for chemicals at the worksite. Two students also mentioned the importance of hearing protection on construction sites. Comments provided related to health hazards related are summarized in Table 7. 


\section{Macrothink}

Table 7. Knowledge Gained Regarding Health Hazards at the Construction Site? $(n=176)$

\begin{tabular}{|c|c|c|c|}
\hline $\begin{array}{l}\text { Number } \\
\text { of } \\
\text { Responses }\end{array}$ & $\begin{array}{l}\% \text { of Valid } \\
\text { Responses }\end{array}$ & Hazard Area & Summary of Comments \\
\hline 135 & $98.5 \%$ & Chemical & $\begin{array}{l}\text { - Workers must be trained to recognize the } \\
\text { GHS Pictograms and use SDS. They must } \\
\text { also understand the dangers chemicals } \\
\text { pose at the worksite. } \\
\text { - Potential damage to target organs and } \\
\text { developing cancer from chemical } \\
\text { exposure } \\
\text { - Health risk from silica and lead exposure }\end{array}$ \\
\hline 2 & $1.5 \%$ & Noise & $\begin{array}{l}\text { - Importance of protecting workers from } \\
\text { construction noise. }\end{array}$ \\
\hline 39 & & & Comment not directed to the question \\
\hline
\end{tabular}

Majority of student feedback (71.2\%) in Focus-4 was related to fall hazards (Table 8). Students came to the realization that falls are the leading cause of fatalities at the worksite and learned how to properly inspect and use their Personal Fall Arrest System (PFAS). The fundamental knowledge they gained in electrical hazards included the importance of locking and tagging out energy, arc blasts, and the importance of replacing electrical equipment rather than fixing them. All comments regarding caught-in hazards were targeted to excavation safety. Three comments provided related to struck-by hazards identified the need to protect workers from falling debris. 
Table 8. Knowledge gained regarding focus-4 hazards from attending the training $(\mathrm{n}=186)$

\begin{tabular}{|c|c|c|c|}
\hline $\begin{array}{l}\text { Number } \\
\text { of } \\
\text { Responses }\end{array}$ & $\begin{array}{l}\text { \% of Valid } \\
\text { Responses }\end{array}$ & Hazard & Summary of Comments \\
\hline 94 & $71.2 \%$ & Falls & $\begin{array}{l}\text { - Correct way to check for Personal Fall } \\
\text { Arrest System (PFAS) fit before using } \\
\text { - Falls are the leading cause of fatalities }\end{array}$ \\
\hline 25 & $18.9 \%$ & Electrical & $\begin{array}{l}\text { Dangerous nature of electrical energy, } \\
\text { especially arc blasts. Electrical energy must } \\
\text { be locked-out before work } \\
\text { - Many thing conduct electricity (including } \\
\text { jewelry) } \\
\text { - Replace extension cords rather than fix } \\
\text { them }\end{array}$ \\
\hline 10 & $7.6 \%$ & Caught-in & $\begin{array}{l}\text { - Workers can easily get trapped and killed } \\
\text { in an excavation that's not shored. }\end{array}$ \\
\hline 3 & $2.3 \%$ & Struck-by & - Falling debris can kill \\
\hline 54 & & & Comment not directed to the question \\
\hline
\end{tabular}

\section{Discussion}

The trainer selection process for this study was designed to include instructors with the most experience facilitating Outreach Training and administering the OSHA Outreach Program. This goal was achieved as all the students in the study felt that the trainers encouraged their participation and 100\% reported that their health and safety questions were answered. Instructors were also able to effectively incorporate their life experience to enhance the training, as a number of students mentioned their instructor sharing an experience, including personal accounts of an instructor receiving an eye injury from a chemical burn while not wearing protective eye goggles and an instructor falling from a ladder. Apparently these testimonials helped reinforce the need for workers to wear protective equipment and take the necessary precautions to avoid injury and illness.

The current 10-hour Construction course matrix of seven required hours and three elective hours was established in 2011. The previous matrix established in 2003 required three hours, including Introduction to OSHA (1-hour), Electrical Safety (1-hour), and Fall Protection (1-hour). The remaining seven hours were electives. 
The time allocated to Introduction to OSHA was doubled in 2011. Trainers are now expected to expand this topic beyond the history of OSHA and employer's general duty requirements of providing a workplace free of recognized hazards to review the process of filing an 11(C) complaint and review employer Recordkeeping Requirements. The 72 valid responses provided by these students show that they were able to distinguish the roles the employer and employees play in this process. It is worth noting that this was the question with the most invalid answers (166 responses). An answer of "yes", "no", or not directed to the question was classified as invalid. There are a number of explanations that may have led to these invalid answers including the possibility that students did not fully comprehend the more general topic. It has been a common complaint from trainers that two hours is not enough to sufficiently cover this topic. Introduction to OSHA is more abstract as opposed to other topics which are more definitive such as the height of a ladder, the need for eye protection, or distance of fall protection, which are measurable.

The subject areas where the students provided the largest number of comments were PPE, ladder safety, and hazardous materials. The students were able to connect a number of important concepts including an employer's requirement to provide PPE free of charge and train them to use it. The largest number of comments related to a specific PPE was for Personal Fall Arrest Systems (PFAS). This was to be expected as a minimum of 1.25 hours of the required 4-hour Focus-4 must be dedicated to fall protection (other Focus-4 topics only require a minimum of 0.5 hours). It's difficult to glean from these data if workers were required to wear a harness as part of their employment. However, student comments concerning such topics as learning how to check for proper fit, inspect for damage, and calculate the developed fall-distances for lanyards and deceleration devices to work properly, suggest that students may have previously been using such fall protection equipment without proper training.

A majority of responding students reported a need to implement at their worksite various administrative controls, especially related to ladder safety. These administrative controls included more diligence when selecting the proper ladder based upon the task, inspecting the ladder, and attention to safe work practices when working on or climbing ladders. Student comments related to health hazards suggest employers may have used this training as an opportunity to cover recent changes to the Hazard Communication Standard incorporating the GHS (Koshy, Presutti \& Rosen, 2014); however, it's uncertain as to how effective the training was at covering other health hazards such as hearing conservation from construction noise.

\section{Conclusion}

This study shows that workers are able to associate controls with the Focus-4 and Health Hazards at their worksite when the 10-hr Construction Outreach Training is facilitated by experienced trainers. Further work may be needed to identify how effectively the Introduction to OSHA training objectives are met in the 10-hr Construction Outreach Training since nearly $70 \%$ of the student responses were dismissed as unresponsive to this question. A section on how to file a complaint with OSHA was added to this module in 2011. The OSHA Outreach Training program expects instructors to review the process of filing a 
labor complaint, through a case study provided by OSHA. This apparent pedagogical gap may suggest that the duration of time currently allotted to cover this topic may not be sufficient. Within this segment of training, Rutgers OTIEC recommends that trainers direct their students to the Local OSHA Area Office for advice on how to file labor grievances as well how to file a complaint through electronic means, in writing and through the national phone number.

The OSHA Outreach Training Program has gone through a progression of changes where less topics and training hours are left to the discretion of instructors. The Outreach guidelines are uniform in all jurisdictions, except California (UCLA, 2014). California -OSHA requires that 9.5 hours of the 10-hr Construction training be required topic hours, as opposed to seven hours. An extra half hour is dedicated to health hazards, an hour to tools and equipment, and an hour to Injury and Illness Prevention Programs (IIPP).

Two of the six elements of IIPP are dedicated to improving employee participation and management commitment to workplace safety (Haight, Yorio, Rost \& Willmer, 2014). These essential components forester a better culture of occupational wellness and safety. An effective IIPP at the worksite will lead to better work conditions and practices, which may in turn lead to fewer labor complaints and better overall success of the company.

Health hazards in construction include hazard communication chemical issues, respirable dusts, including silica, and construction noise. OSHA also recommended adding heat stress awareness to this section of the training in 2013. The impact of hazard communication training is visible from this study; however, it's unclear as to how effective the other sections were covered. Expanding health hazards to 1-hr from the current $0.5 \mathrm{hr}$ will give the trainers the opportunity to cover this topic in greater detail.

\section{References}

Albert, A., Hallowell, M. R., Kleiner, B., Chen, A., \& Golparvar-Fard, M. (2014). Enhancing construction hazard recognition with high-Fidelity augmented virtuality. Journal of Construction Engineering and Management.

Bahn, S. (2013). Workplace hazard identification and management: The case of an underground mining operation. Safety Science, 57, 129-137.

Bureau of Labor Statistics (BLS). (2013). Revision to the 2011 census of fatal occupational injuries (CFOI) counts. Retrieved December 11, 2014, from the World Wide Web: http://www.bls.gov/iif/oshwc/cfoi/cfoi_revised11.pdf

Bureau of Labor Statistics (BLS). (2014). Employer reported workplace injury and illness summary. Retrieved on December 29, 2014, from the World Wide Web: http://www.bls.gov/news.release/osh.nr0.htm

Carter, G., \& Smith, S. D. (2006). Safety hazard identification on construction projects. Journal of Construction Engineering Management, 132:2(197), 197-205.

Dong, X., Entzel, P., Men, Y., Chowdhury, R., \& Schneider, S. (2004). Effects of safety and 


\section{Macrothink}

Journal of Safety Studies

ISSN 2377-3219

2015, Vol. 1, No. 1

health training on work-related injury among construction laborers. Journal of occupational and environmental medicine, 46(12), 1222-1228.

Fechhelm, A. R. (2010). Perceptions of OSHA 10-hour training effectiveness within eau claire, wisconsin trade union (Master's thesis).

Haight, J. M., Yorio, P., Rost, K. A., \& Willmer, D. R. (2014). Safety management systems: comparing content \& impact. Professional Safety, 59(5), 44-51.

Koshy, K., Presutti, M., \& Rosen, M. A. (2014). Implementing the hazard communication standard final rule: lessons learned. Journal of Chemical Health and Safety.

New York City. (2008). Local laws of the city of new york. no. 41. Retrieved December 22, 2014, from http://www.nyc.gov/html/dob/downloads/pdf/ll41of2008.pdf

Occupational Safety and Health Administration (OSHA). Outreach training program. Retrieved December 29, 2014, from https://www.osha.gov/dte/outreach

Ruttenberg, R. (2013). The economic and social benefits of OSHA-10 training in the building and construction trades. CPWR- The Center for Construction Research and Training.

University of California San Diego, Extension (2014). Cal/OSHA partnership program.

Retrieved December 29, 2014, from the World Wide Web: http://osha.ucsd.edu/documents/calOshaOutreachConstruction10Outline.pdf?29-Dec-14

\section{Copyright Disclaimer}

Copyright for this article is retained by the author(s), with first publication rights granted to the journal.

This is an open-access article distributed under the terms and conditions of the Creative Commons Attribution license (http://creativecommons.org/licenses/by/3.0/). 